\title{
OPERATING A NESTBOX LINE A 13 YEAR SUMMARY
}

\section{BILL ANAKA, Box 211, Yorkton, SK S3N 2 V7}

Nestbox lines are becoming a common sight along roads in western Canada. Most, if not all, of these lines are intended to increase the number of Mountain and Eastern Bluebirds, two species that suffer from loss of habitat and competition for limited nest sites. Close observation of many lines reveals a low percentage of bluebird occupancy for a number of reasons: poor habitat, competition with Tree Swallows, House Sparrows and other species, poor box design and little or no maintenance.

My wife Joyce and I for several years monitored a $50-\mathrm{km}$ line from Yorkton, SK to Good Spirit Lake Provincial Park (GSLPP) with very low bluebird occupancy. All but the last six $\mathrm{km}$ near the lake ran through cultivated land with numerous farmyards. Most nestboxes were occupied by Tree Swallows or House Sparrows.
C. Stuart Houston of Saskatoon mentioned that ideal bluebird habitat was well-grazed pasture. With that in mind, we started a new nestbox line in the Good Spirit Community Pasture (GSCP), operated by Saskatchewan Rural Development (SRD). This pasture is located along the west boundary of GSLPP. It consists of 26 sections of land (approx. 6700 hectares). The topography is slightly rolling with wooded bluffs and a number of seasonal creeks with associated willow growth. The pasture is bisected by provincial highway \#47.

Methods. Starting in 1984, 30 nestboxes were placed along the highway through the pasture at distances of 300-400 m apart. Ten more boxes were added in 1985. All the boxes in both years were occupied by Tree Swallows. The breakthrough came in 1986 when two Mountain Bluebird nests fledged a total of 11 young. In

\begin{tabular}{|c|c|c|c|c|}
\hline Year & \# Sites & $\begin{array}{l}\text { \# Sites with } \\
\text { Second Box }\end{array}$ & $\begin{array}{c}\text { \# Occupied } \\
\text { Boxes }\end{array}$ & $\begin{array}{l}\text { \% Boxes from } \\
\text { Occupied Site }\end{array}$ \\
\hline 1984 & 30 & 0 & 0 & 0 \\
\hline 1985 & 40 & 0 & 0 & 0 \\
\hline 1986 & 40 & 0 & 2 & 5 \\
\hline 1987 & 40 & 0 & 4 & 10 \\
\hline 1988 & 41 & 7 & 9 & 22 \\
\hline 1989 & 41 & 41 & 32 & 78 \\
\hline 1990 & 52 & 51 & 36 & 69 \\
\hline 1991 & 85 & 81 & 70 & 82 \\
\hline 1992 & 103 & 103 & 91 & 88 \\
\hline 1993 & 103 & 103 & 92 & 89 \\
\hline 1994 & 103 & 103 & 98 & 95 \\
\hline 1995 & 103 & 103 & 96 & 93 \\
\hline 1995 & 108 & 108 & 99 & 92 \\
\hline
\end{tabular}


Monitoring of the line begins in mid-May and ends after the last brood fledges in mid- to late August. The trail is monitored weekly. After the initial trip, individual sites are checked frequently enough to record the complete egg clutch, progress of the young and the number of young within one week of fledging. All early nests are checked for renests. The number of visits to an individual nest during a season range from five to eight, depending on nest contents and whether there is a renest attempt.

Young birds are aged to determine the time for the next visit. Originally we used three broad age groups: "N" denoted newly hatched, naked young, "P" pin or partly feathered and "F" fully feathered young. In 1995 a more age-specific method was initiated. Referring to the series of excellent colour photographs of nestlings in Bryan R. Shantz's book, all young are aged as to number of days since hatching. ${ }^{5}$ This determines the timing of all subsequent visits.

In 1996 we kept track of our monitoring efforts. From 21 May to $31 \mathrm{Au}$ gust we made 15 trips, totalling 996 $\mathrm{km}$ and 72 hours. The line starts 6 $\mathrm{km}$ from home. Individual trips range from four to seven hours.

Problems. A major predator problem developed in 1991. Raccoons discovered an easy meal in every active nestbox. During the renest period (late June to mid-July) in 1991 raccoons destroyed 20 bluebird nests and an equal number of swallow nests. In one instance a raccoon raided every nestbox for a distance of $5 \mathrm{~km}$. Raccoon predation at a nest is readily identified by scratches on the box exterior, disturbed nest contents and bluebird wing and tail 
feathers on the ground beneath the nest. In conversation with Louise Horstman and Ted Code, coordinators of the Prairie Nestbox Monitoring Program, they mentioned that Ronald A. Bittner of Abernethy, SK had developed a box style that was relatively raccoon proof. Ron provided plans for the box (Plan A). ${ }^{3}$ This box used internal and external predator guards. The guards are 3.8 $\mathrm{cm}$ wide (standard 2" $\times 4^{\prime \prime}$ construction material). The internal guard is the width of the box, with the inner surface tapered. The external guard is attached to front of the box and, in effect, becomes an extension of the entrance hole. With both guards in place the thickness of the front wall increases to $9.5 \mathrm{~cm}$. The guards (as per the Plan A box) were added to all the standard boxes. As well contact with Myrna Pearman at the Ellis Bird Farm, Lacombe, $A B$ resulted in the discovery of another raccoon ' resistant box, the Shantz box. ${ }^{5}$ We have also added Ron Bittner's Plan B box and a modified version of the Peterson box. ${ }^{2,3}$ We now have 25 boxes of each of the four styles located at random along the line, with one standard and one experimental box at each site. To date, bluebirds have shown a preference for the experimental boxes. Most important, raccoon predation is no longer a problem.

Other predators and conflict with other species are minor factors on our line. With the area largely uninhabited, House Sparrows are not a problem. European Starlings, although present, average less than one nest per year. (Editor's note: The author uses a 1.75 inch hole, considerably larger than the recommended 1.5 inch. A Starling has difficulty with holes smaller than 1.6 inch, while 1.5 inch is about the lower limit for the Mountain Bluebird and is ideal for the Eastern Bluebird. Anaka tried 1.5 inch holes alongside 1.75 inch and discovered that bluebirds chose the larger holes twice as often as the smaller ones. As he has few problems with Starlings he now uses the larger hole on all boxes.) With frequent monitoring we know the ages of the young so we can prevent premature attempts at fledging by avoiding those boxes. Deer mice will occupy a nestbox over winter and at times will still be present at nesting time. A pre-season check of sites subject to mouse presence controls the problem. Deer mouse presence is a greater problem for the bander than for the birds. Precautions include using a mask and dust control while cleaning the boxes.

Theft and vandalism are a reality on any nestbox line, particularly when the area is uninhabited. Every year several boxes disappear. Usually only one box at a site is removed, inevitably the newer one. Vandalism is less frequent; one or two boxes a year are the victims of target practice by frustrated hunters in the fall after nesting season is over.

Results. Adding a second box at each site eliminated the swallow conflict and bluebird production increased accordingly (Table 2). Occupancy by bluebirds of one box at each site remains at over $90 \%$. Modifying standard boxes and incorporating new box designs controlled the raccoon problem. The number of young fledged annually ranges from 500 to 600 plus. The major factor influencing this variation is weather, particularly at fledging and renest time. Prolonged cold, wet conditions in late June and early July result in the loss of one or more young in some nests and a marked decrease in the number of renests. 1996 was 


\begin{tabular}{|c|c|c|c|c|c|c|c|c|c|}
\hline \multirow[b]{2}{*}{ Year } & \multicolumn{3}{|c|}{ Early and First Nests } & \multicolumn{3}{|c|}{ Late and Renests } & \multicolumn{3}{|c|}{ Total - All Nests } \\
\hline & $\begin{array}{c}\text { \# of } \\
\text { Nests }\end{array}$ & $\begin{array}{l}\text { \# of } \\
\text { Fledg. }\end{array}$ & $\begin{array}{l}\text { Av. \# } \\
\text { Fledg. }\end{array}$ & $\begin{array}{c}\text { \# of } \\
\text { Nests }\end{array}$ & $\begin{array}{l}\# \text { of } \\
\text { Fledg. }\end{array}$ & $\begin{array}{l}\text { Av. \# } \\
\text { Fledg. }\end{array}$ & $\begin{array}{c}\text { \# of } \\
\text { Nests }\end{array}$ & $\begin{array}{l}\text { \# of } \\
\text { Fledg. }\end{array}$ & $\begin{array}{l}\text { Av. \# } \\
\text { Fledg. }\end{array}$ \\
\hline 1984 & 0 & & & 0 & & & 0 & & \\
\hline 1985 & 0 & & & 0 & & & 0 & & \\
\hline 1986 & 2 & 11 & 5.5 & 0 & & & 2 & 11 & 5.5 \\
\hline 1987 & 4 & 20 & 5.0 & 1 & 6 & 6.0 & 5 & 26 & 5.2 \\
\hline 1988 & 9 & 44 & 4.9 & 2 & 8 & 4.0 & 11 & 52 & 4.7 \\
\hline 1989 & 29 & 130 & 4.5 & 18 & 56 & 3.1 & 47 & 186 & 4.0 \\
\hline 1990 & 32 & 156 & 4.9 & 18 & 52 & 2.9 & 50 & 208 & 4.2 \\
\hline 1991 & 68 & 323 & 4.8 & 46 & 100 & 2.2 & 114 & 423 & 3.7 \\
\hline 1992 & 82 & 348 & 4.4 & 61 & 202 & 3.3 & 143 & 550 & 3.8 \\
\hline 1993 & 82 & 381 & 4.6 & 39 & 115 & 2.9 & 121 & 496 & 4.1 \\
\hline 1994 & 87 & 380 & 4.4 & 48 & 146 & 3.0 & 135 & 526 & 3.9 \\
\hline 1995 & 83 & 406 & 4.9 & 63 & 167 & 2.6 & 146 & 573 & 3.9 \\
\hline 1996 & 99 & 461 & 4.6 & 56 & 216 & 3.9 & 155 & 677 & 4.4 \\
\hline Total & 577 & 2,660 & 4.6 & 352 & 1,068 & 3.0 & 929 & 3,728 & 4.0 \\
\hline \multicolumn{10}{|c|}{$\begin{array}{l}\text { Early nest denotes a nest with at least one egg laid by } 31 \text { May. Late nest denotes a nest with the first egg laid } 1 \\
\text { June or later. Renest denotes a second nest at the same site. }\end{array}$} \\
\hline
\end{tabular}

an ideal nesting season with no weather-related problems. A total number of 677 young fledged reflects this.

Included in the bluebird totals are several Eastern Bluebird nests. This species is not a regular resident. Since the start of the line in 1984 Eastern Bluebird nests have been recorded in five years. The total of 11 nests, including three renests, fledged 42 young.

We do not monitor Tree Swallow nests as frequently as the bluebird nests. This is mostly due to time constraints. Nests are checked for occupancy and later for presence of young. Approximate success is determined at cleaning time. The total number of nests and young fledged equals or exceeds the bluebird totals. An exception occurred in 1993 when prolonged cold, wet conditions in early July resulted in the loss of 30 swallow nests.

Discussion. We established the
Good Spirit Community Pasture trail for the purpose of increasing the bluebird population in an area with good habitat but a lack of natural nest sites. It is a learning experience. Along the way we encountered problems: competition from Tree Swallows and predation by raccoons. These problems were overcome with the assistance and advice of a number of people. In retrospect, and despite setbacks, the trail is a success. The fledging of over 3,700 bluebirds in the last 11 years attests to that.

There are 56 community pastures managed by SRD in Saskatchewan along with 57 Prairie Farm Rehabilitation Administration (PFRA) pastures. Many provide excellent bluebird habitat and the potential for almost unlimited nestbox lines.

An enjoyable side benefit of monitoring in a community pasture area is seeing other species of wildlife and numerous wildflowers that fill every ditch and extend out into many of the 


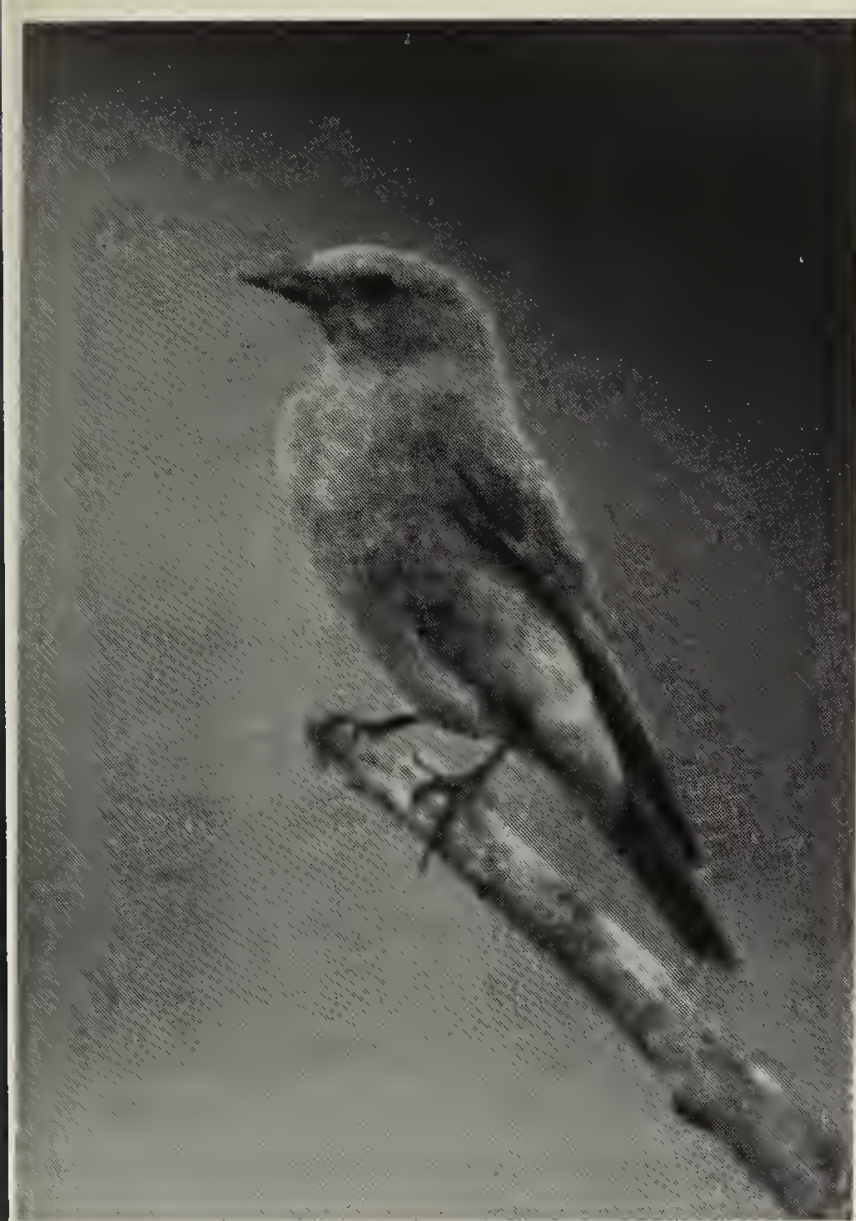

Mountain Bluebird

Andrius Valadka

fields. The large herds of cattle and the absence of cultivated fields add to the overall impression of a much earlier period in time before the advent of homesteads and intense human activity.

Acknowledgements. Although the operation of the nestbox line is primarily a two-person endeavour, the assistance of numerous individuals is appreciated. Thanks to C. Stuart Houston, Ronald Bittner, Myrna Pearman, Louise Horstman and Ted Code for their suggestions, references and nestbox plans. Thanks also to management and staff of the Good Spirit Community Pasture, to private land owners for the use of their fences for nestbox erection and to Julia Wiwchar, a very capable assistant on many of our monitoring trips. Also thanks to an anonymous reviewer who critiqued the first draft of this paper and offered helpful suggestions.

1. ANONYMOUS. (c. 1950). Bird houses and their occupants. Canada Department of Mines and Resources, Ottawa. 9pp.

2. ANONYMOUS. 1990. The Peterson box. Sialia 12(4):142.

3. BITTNER, R.A. 1995. Experimental nestboxes for bluebirds: an update. Blue Jay 53:200-202.

4. PEARMAN, M. 1992. Nestboxes for prairie birds. Ellis Bird Farm Limited. 80pp.

5. SHANTZ, B.R. 1986. Mountain Bluebird management. Deer Ridge Consulting Ltd. and the North American Bluebird Society. 32 pp.

The term godwit (Hudsonian and Marbled Godwits) comes from the Old English god wiht meaning good creature - presumably because they are good eating.

Lead shot embedded in a bird's flesh does not cause poisoning. It is shot mistakenly picked up as seed and digested that leads to its death. 